\title{
Molecular Characterization of Enterotoxigenic Bacillus cereus Species Isolated from Meat Using Conventional PCR and Multiplex PCR
}

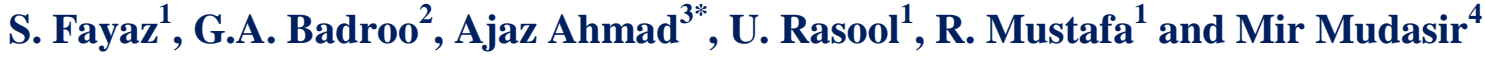 \\ ${ }^{1}$ Department of Food Technology, Doon Valley Institute of Engineering and Technology, \\ Karnal, Haryana, India \\ ${ }^{2}$ Department of Veterinary Microbiology, SKUAST-Jammu, India \\ ${ }^{3}$ Department of Veterinary Pathology, GADVASU, Ludhiana, Punjab, India \\ ${ }^{4}$ Department of Veterinary Pathology, SKUAST-Jammu, India \\ *Corresponding author
}

\section{A B S T R A C T}

A total of 120 samples comprising 40 each of raw mutton, raw chicken and chicken biryani were analyzed for the enter toxigenic profile of Bacillus cereus. Out of 52

\section{Keywords}

Bacillus cereus,

Meat, PCR,

Enterotoxin,

HBL, NHE.

Article Info

Accepted:

04 July 2017

Available Online:

10 September 2017 presumptive $B$. cereus isolates confirmed by conventional PCR method, 44 isolates produced a product of 475 base pairs on PCR by targeting species specific gyrB gene. Hence the incidence of $B$. cereus in meat and meat products was found to be 36.66 percent. Incidence of $B$. cereus in raw mutton, raw chicken and chicken biryani was 35 per cent, 30 per cent and 45 per cent. On subjecting to multiplex PCR, all the 44 isolates carried at least one of the six enterotoxin genes. One or more genes of $H B L(h b l C A D)$ and NHE (nheABC) complex were present in $28(63.63 \%)$ and $39(88.6 \%)$ isolates respectively. Based on the presence of one or more genes of $h b l C A D$ and $n h e A B C$ complexes all the 44 isolates were further divided into six groups: G1 comprised of 20.45 per cent isolates which carried all the genes of both HBL and NHE complex while asG2 comprised of 31.81 per cent isolates which carried one or more genes of both HBL and NHE complex.. G3 comprised of 4.5per cent isolates which carried all the three genes of HBL while as G4comprised of 6.8 per cent isolates which carried one or more genes of HBL complex. G5 comprised of 18.18 per cent isolates which carried all the genes of NHE complex where as G6 comprised of 18.18 per cent isolates which carried one or more genes of NHE complex.

\section{Introduction}

The major cause of morbidity and mortality all over the world are reported to be due to food borne diseases which pose a serious threat to public health. Both developed as well as developing countries suffer from large number of food borne out breaks and the incidences are showing increasing trend on global level. The increasing trans-border movement of people, animals and animal products, rapid urbanization, rapid increase in number of immune-compromised people, food handling and consumption pattern changes and pathogens showing antibiotic resistance play significant role in increasing the outbreaks all over the world (Unnevehr, 2003). The pathogens transmitted through food contribute 30 per cent to globally emerging infections (Carlin et al., 2009). 
Majority of the cases go unnoticed as symptoms are mild often associated with diarrhea and vomiting. Though food borne diseases occur in both developing as well as developed countries but most deaths occur in poor countries (Tauxe et al., 2010). The foodborne illnesses are caused by various pathogens yet Campylobacter species, Salmonella spp, Listeria monocytogens, Bacillus cereus and E. coli O157: H7 are responsible for majority of outbreaks (Velusamy et al., 2010). Bacillus cereus (B. cereus) plays a significant role in food borne illness along with other bacteria as it was responsible for seventy three outbreaks out of 5141 food borne outbreaks during a period between 1982 to 1986 involved 1323 cases (Shinagawa, 1990).

The primary diagnosis of $B$. cereus food poisoning is done by isolation of the pathogen from specimens like faeces, vomitus and foods etc. Though Bacilli have been presumptively identified and characterized based on their morphology and biochemical profile yet use of these conventional as well as 16 DNA sequence analysis tests may be insufficient to differentiate B. cereus from other members of B. cereus group as these members share a quite significant degree of genetic and phenotypic similarities (Rhodehamel and Harmon, 2001). The organisms isolated from meat and meat products in different regions might have enough diversity at genetic level and can be classified at genetic level by using molecular techniques like polymerase chain reaction.

\section{Materials and Methods}

A total of 120 samples, 40 each from raw mutton and raw chicken were collected in sterile containers from various butcher shops and restaurants and 40 samples of chicken biryani were collected aseptically from various retail outlets and restaurants in and around Srinagar city. The samples were brought to the laboratory on ice and processed within two hours of collection.

\section{Isolation of $B$. cereus in meat and meat products}

Out of 120 samples of meat and meat products, which comprised of 40 samples each of raw mutton, raw chicken and chicken biryani were assessed for the presence of $B$. cereus. Out of 120 samples, 44 samples were found positive for $B$. cereus with an overall incidence of 36.66 per cent. Among 44 isolates, 14 were found in raw mutton, 12 in raw chicken and 18 in chicken biryani with an incidence of 35 per cent, 30 per cent and 45 per cent in raw mutton, raw chicken and chicken biryani, respectively.

\section{Confirmation of $B$. cereus using PCR}

From 120 samples, phenotypically identified presumptive $B$. cereus isolates were further confirmed by PCR. The 52 presumptive isolates were subjected to PCR for obtaining a product size of 475 bp by targeting species specific gyrB gene. Out of 52, 44 presumptive isolates possessed $g y r B$ gene and were confirmed as B. cereus (Fig. 1).

\section{Preparation of DNA template by boiling and snap chilling method}

The cultures were inoculated in $5 \mathrm{ml}$ nutrient broth and incubated in shaker incubator (150 $\mathrm{rpm}$ ) for $5 \mathrm{~h}$ at $32^{\circ} \mathrm{C}$. Cells were collected from $1 \mathrm{ml}$ of culture broth by centrifugation @ $5000 \mathrm{rpm}$ for 3 minutes. The cell pellet was washed once with $500 \mu$ l sterile nuclease free water, the pellet was resuspended in 100 $\mu \mathrm{l}$ of sterile nuclease free water, boiled for 10 min and tubes were kept in crushed ice for 20 min. The chilled samples were centrifuged @ $6000 \mathrm{rpm}$ for $5 \mathrm{~min}$ and the supernatant collected served as template 
Molecular characterization of $B$. cereus isolates using $\mathrm{mPCR}$

The isolates were characterized by multiplex polymerase chain reaction by targeting six enterotoxigenic genes ( $h b l C D A$ and nhe $A B C$, genes) as per the method described by Ngamwongsatit et al., (2008) with slight alterations. The multiplex PCR was standardized by using reference strain of $B$. cereus (NCTC11143).

\section{Multiplex PCR targeting six enterotoxingenic genes of $\boldsymbol{B}$. cereus}

The multiplex PCR was standardised for detecting six enterotoxin genes namely $h b l C A D$ and $n h e A B C$ by the methodologies as described by Ngamwonsatit et al., (2008) with suitable modifications. The multiplex PCR was performed in a final volume of $25 \mu 1$ using $0.2 \mathrm{ml}$ thin wall sterile and nuclease free PCR tubes (Eppendorf, Germany). The PCR mixture contained a final concentration of 5 $\mu \mathrm{l}$ of template DNA, 1X PCR buffer, $1.5 \mathrm{mM}$ $\mathrm{MgCl}_{2}, 200 \mu \mathrm{M}$ of each dNTP, 0.2 to $0.4 \mathrm{Mm}$ of primers and 5U of TaqDNA polymerase (Promega corporation, U.S.A Madison) in two parts, taking three genes in each part.

The multiplex polymerase chain reaction was carried out in a thermal cycler (Eppendorf, Microcycler). The cycling conditions for the PCR reaction mixture consisted of an initial denaturation at $95^{\circ} \mathrm{C}$ for 5 minutes, followed by 30 cycles of $94^{\circ} \mathrm{C}$ for 45 seconds, $54^{\circ} \mathrm{C}$ for 1 minute, $72^{0} \mathrm{C}$ for $2 \mathrm{~min}$ and a final extension at $72^{\circ} \mathrm{C}$ for 5 minutes. The confirmation and resolution of the PCR product was done by agarose gel electrophoresis for the amplicon sizes of 695bp, 1018bp, 884bp, 759bp, 935bp and 618bp.

\section{Results and Discussion}

Out of 120 samples of meat and meat products, which comprised of 40 samples each of raw mutton, raw chicken and chicken biryani were assessed for the presence of $B$. cereus. Out of 120 samples, 44 samples were found positive for $B$. cereus with an overall incidence of 36.66 per cent.

Fig.1 Agarose gel electrophoresis depicting amplified PCR product of gyrB gene from genomic DNA of B. cereus for confirmation

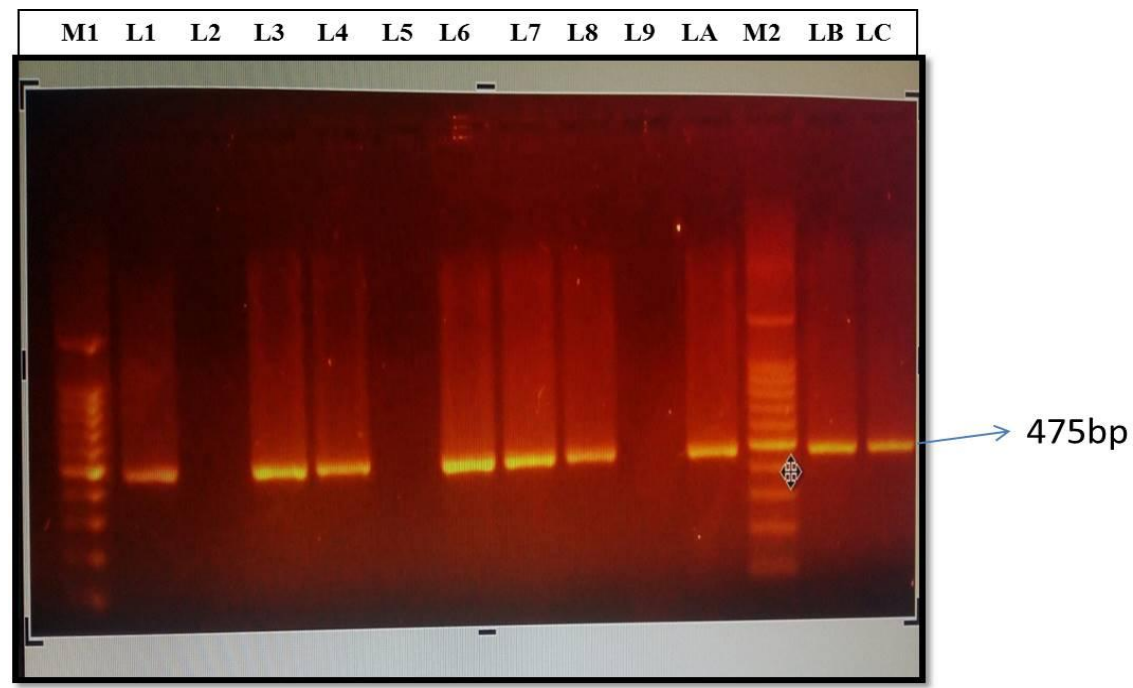

M1 and M2-100 bp DNA ladder; L2, L5 and L9 - Negative controls; LA-Positive control; L1, L3, L4, L6, L7, L8, LB and LC-Samples positive for gyrB gene 
Fig.2 Agarose gel electrophoresis of mPCR products amplified from genomic DNA of B. cereus for $h b l C A D$ gene

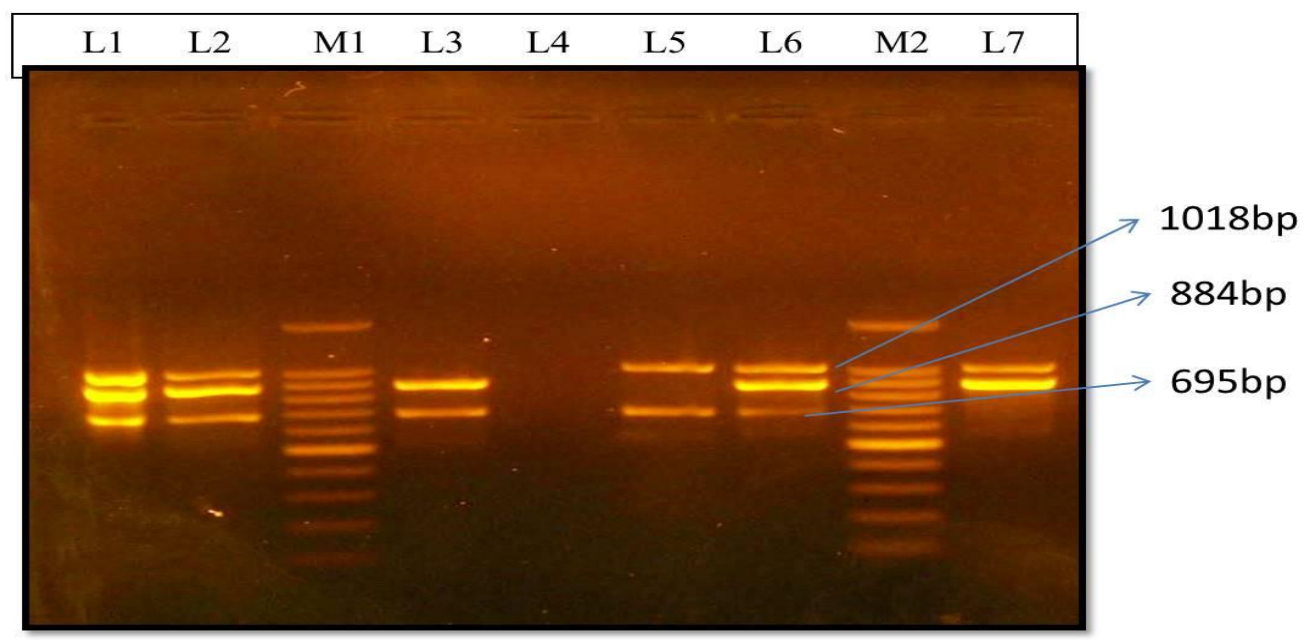

M1 and M2-100 bp DNA ladder; L1-Positive control; L4-Negative control; L2 and L6-All the three genes of HBL complex; L3, L5 and L7-Two genes of HBL complex

Fig.3 Agarose gel electrophoresis of mPCR products amplified from genomic DNA of $B$. cereus for $n h e A B C$ gene

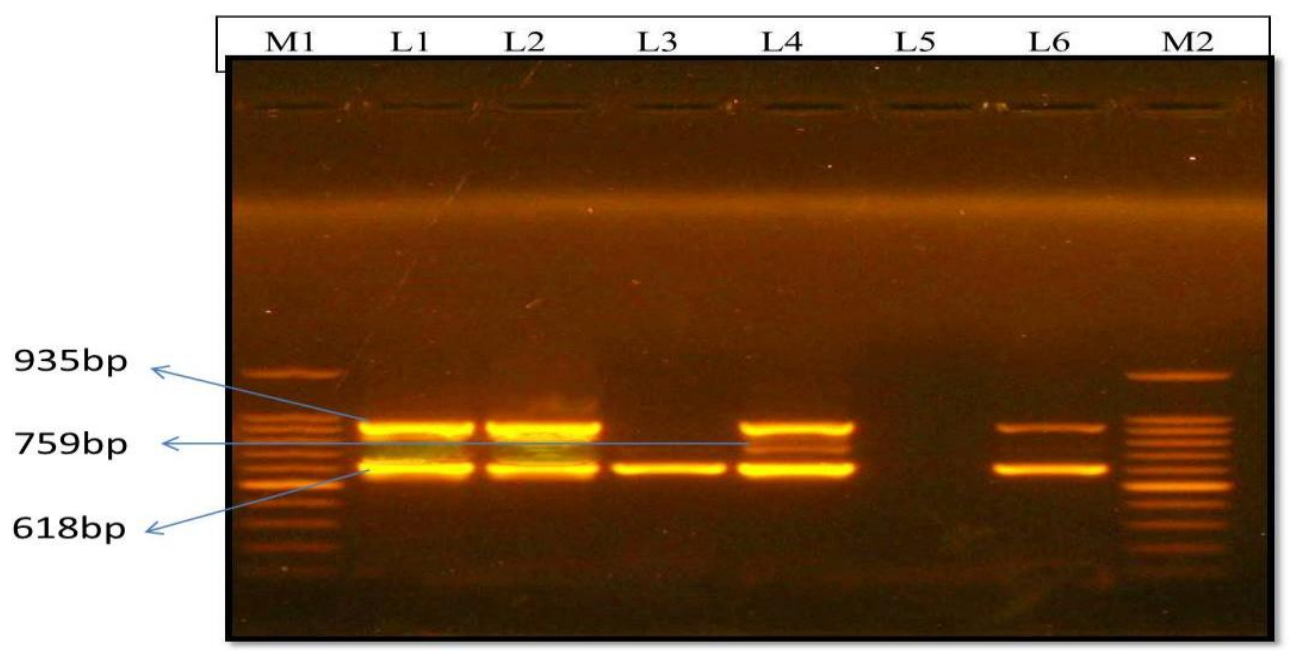

M1 and M2-100 bp DNA ladder; L6-Positive control; L5-Negative control; L1 and L2-Two genes of NHE complex; L4-Three genes of NHE complex; L3-One gene of NHE complex

Among 44 isolates, 14 were found in raw mutton, 12 in raw chicken and 18 in chicken biryani with an incidence of 35 per cent, 30 per cent and 45 per cent in raw mutton, raw chicken and chicken biryani, respectively.

All the 44 isolates of $B$. cereus confirmed on molecular basis were subjected to multiplex PCR as described by the Ngamwongsatit et al.,
(2008) with suitable modifications. The multiplex PCR was carried in two parts, in one part HBL complex genes were characterized (Fig. 2) and in other part NHE complex genes were characterized (Fig. 3). Out of 44 isolates, 39 were having one more genes of NHE complex with an overall incidence of this complex as 88.6 per cent and similarly 28 isolates possessed one or more genes of $\mathrm{HBL}$ 
complex with an overall incidence of 63.63 per cent of this complex. However, all the six genes of the NHE and HBL complexes were not present in all the isolates, so the isolates needed to be further divided into various groups. Hence all the 44 isolates were further divided into 6 groups; G1 to G6 depending upon the distribution of these six Enterotoxigenic genes hblA, hblC, hblD, nheA, nheB and nheC. Based on the distribution of six genes, the highest number of $B$. cereus isolates i.e. $14(31.8 \%)$ were present in $\mathrm{G} 2$, in which one or more genes of both NHE and HBL complex were absent followed by G1 in which $9(20.45 \%)$ isolates carried all the genes of both HBL and NHE complex. G5 comprised of $8(18.18 \%)$ isolates which carried all the genes NHE complex while as G6 comprised of $8(18.18 \%)$ isolates which carried one or two genes of NHE complex. G3 comprised of $2(4.55 \%)$ isolates which carried all the genes of HBL complex while as G4 comprised of $3(6.8 \%)$ isolates which carried one or two genes of HBL complex. Molecular confirmation by detecting $\operatorname{gyr} B$ gene is helpful in differentiating $B$. cereus from rest of the members of the B. cereus group. All the isolates carried at least one toxin gene which directly indicates the pathogenicity potential of $B$. cereus.

The effective use of quality control and safety measures during production/manufacture besides creating awareness among food handlers and consumers becomes necessary to ward off the menace of $B$. cereus and other food poisoning organisms.

\section{References}

Carlin, F., Brillard, J., Broussolle, V., Clavel, T., Duport, C., Jobin, M., Guinebretiere, M. H., Auger, S., Sorokine, A., Nguyen-
The, C. 2009. Adaptation of Bacillus cereus, an ubiquotious worldwide distributed foodborne pathogen, to a changing environment. Food Res. Int., 30: 30-30.

Ngamwongsatit, P., Buasri, W., Pianariyanon, P., Pulsrikarn, C., Ohba, M., Assavanig, A., Panbangred, W., 2008.Broad distribution of enterotoxin genes (hblCDA, nheABC, cytK and entFm) among Bacillus thuringiensis and Bacillus cereus as shown by novel Primers. International Journal of Food Microbiology Shinagawa, K., 1990.Analytical methods for Bacillus cereus and other Bacillus species. Int. J. Food Microbiol, 10, 125-142

Rhodehamel, E. J., Harmon, S. M. 2001. Bacillus cereus. In Bacteriological Analytical Mannual (Jackson, G. J., Merker, R. I. and Bandler, R.eds.) Centre for food safety and Applied Nutrition, U.S, Food and Drug Administration, College Park, M. D. http://www.cfsan.fda.gov/ ebam-14.html.

Shinagawa, K., 1990. Analytical methods for Bacillus cereus and other Bacillus species.nt. J. Food Microbiol, 10: 125-41.

Tauxe, R. V., Doyle, M. P., Kuchenmuller, T., Schlundt, J., Stein, C.E. 2010. Evolving public health approaches to the global challenge of foodborne infections. Int. J. Food Microbiol, 139: 16-28.

Unnevehr, L. J., 2003. Food safety in food security and trade: An overview. 2020 Vision for Food, Agriculture and the Environment, 10: 1-7.

Velusamy, V., Arshak, K., Korostynska, O., Oliwa, K., Adley, C. 2010. An overview of foodborne pathogen detection; in the perspective of biosensors. Catherine Adley Biotechnol. Adv., 28: 232-254.

\section{How to cite this article:}

Fayaz, S., G.A. Badroo, Ajaz Ahmad, U. Rasool, R. Mustafa and Mir Mudasir. 2017. Molecular Characterization of Enterotoxigenic Bacillus cereus Species Isolated from Meat Using Conventional PCR and Multiplex PCR. Int.J.Curr.Microbiol.App.Sci. 6(9): 324-328. doi: https://doi.org/10.20546/ijcmas.2017.609.041 